\title{
Ruang Lingkup Pasar Bebas
}

\author{
Indah Nuansa Annisa \\ Jurusan Perbankan Syariah Fakultas Ekonomi Dan Bisnis Islam
}

Indahnuansaannisa@Gmail.Com

\begin{abstract}
Abstrak
Dinamika lingkungan bisnis, kepemimpinan, perubahan-perubahan yang mengalir dengan cepat, kemajuan teknologi komunikasi dan informasi, transportasi serta teknologi di bidang manufaktur telah membawa organisasi bisnis menuju kondisi bisnis yang mengacu pada pasar global. Dalam era global, dunia menjadi tanpa batas (unborderless), mobilitas sumber daya menjadi semakin cepat, informasi menjadi instan, organisasi dihadapkan pada berbagai peluang dan sekaligus tantangan yang semakin kompleks. Pada kondisi ini aturan main dalam bisnis juga mengalami revolusi yang sangat cepat. Perubahan telah memunculkan "the new rule of the game" dan organisasi bisnis dituntut untuk dapat bertindak cepat dan fleksibel demi eksistensi dan perkembangannya di masa yang akan datang.

Perubahan lingkungan berimplikasi pada perubahan strategi organisasi. Selama ini organisasi bisnis bersaing dengan basis produk dan pasar, artinya kepemimpinan produk dan pasar menjadi penentu keunggulan organisasi. Kondisi ini kemudian berubah, di mana dalam upaya untuk menciptakan keunggulan bersaing organisasi fokus pada persaingan dengan basis sumber daya dan kompetensi. Perkembangan ke depan organisasi dituntut untuk dapat bersaing dengan basis talenta dan impian (talent and dream). Singkatnya organisasi harus selalu bersahabat dengan perubahan (in friendship with change), dan berpandangan jauh ke depan agar menjadi pemimpin perubahan itu sendiri.
\end{abstract}

\section{Kata kunci : dinamika,bisnis, perubahan dan organisasi}




\section{Pengertian pasar bebas menurut para ahli}

Adam smith, yang sering dijuluki sebagai bapak ekonomi mengatakan bahwa pasar bebas sudah memberikan kebebasan pada masyarakat luas untuk bisa membuat dan melakukan kegiatan jual beli barang sesuka hati mereka.

Selain itu, pasar bebas pun mampu membuka pasar hingga keluar negeri dan melahirkan persaingan ekonomi yang lebih luas yang mana setiap orang secara alami tentu akan lebih memilih barang dengan harga yang murah demi memperkaya dirinya sendiri tanpa adanya campur tangan pemerintah.

Disisi lain, David Ricardo menjelaskan bahwa pasar bebas adalah suatu kegiatan perdagangan luar negeri yang melibatkan lebih dari dua negara yang masing-masing diantaranya akan melakukan perdagangan tanpa ada masalah dari pihak pemerintah.

Artinya, setiap masyarakat memiliki kebebasan dalam melakukan perdagangan antar negara tanpa hambatan dari pihak pemerintahannya masing-masing.

Berdasarkan penjelasan dari para ahli diatas, bisa kita tarik kesimpulan bahwa pasar bebas memiliki hubungan yang erat dengan kebijakan pemerintah tentang suatu perdagangan. Artinya, pemerintah tidak akan melakukan tindakan diskriminatif atau menghambat proses perdagangan, terutama kegiatan impor dan ekspor barang. (wijayanti, 2016) 


\section{Tujuan pasar bebas}

a) Membuka peluang ekonomi

Pasar bebas dapat membuka peluang ekonomi dengan cara memperluas pasar. Produk yang awalnya diproduksi untuk dijual di dalam negeri, dapat dijual ke luar negeri dengan mudah. Tidak adanya pajak membuat pasar menjadi lebih luas karena tidak dibatasi oleh pajak antarnegara yang mahal. Terbukanya pasar membuat produsen dalam negeri dapat mengekspor barang dalam jumlah besar namun biaya ekspor yang rendah. Hal ini membuat negara memiliki komoditas ekspor unggulannya yang dapat meningkatkan perekonomian.

b). Meningkatkan perekonomian

Diselenggarakannya pasar bebas bertujuan meningkatkan pendapatan negara juga perekonomian penduduknya. Pasar yang luas memberikan permintaan produk yang lebih besar bagi produsen dalam negeri. Semakin banyak permintaan pasar, maka akan semakin besar pula peningkatan ekonomi yang terjadi. Selain itu, terbukanya pasar yang luas mengundang datangnya para investor asing untuk mendirikan bisnis di dalam negeri. Pembukaan usaha baru maupun pengembangan usaha menjadi lebih besar dapat memberikan 
lapangan pekerjaan. Hal ini dapat mengurangi adanya pengangguran serta meningkatkan pendapatan per kapita masyarakat. (Nainggolan, 2018)

c). Meningkatkan teknologi

Pasar bebas memungkinkan teknologi yang lebih maju dari luar negeri untuk masuk dengan mudah ke dalam negeri. Dengan adanya pasar bebas, peningkatan teknologi bisa dilakukan dengan mudah dan merata. Selain meningkatkan teknologi, persaingan ketat pasar bebas juga menuntut peningkatan sumber daya manusia suatu negara.

d). Memenuhi kebutuhan dalam negeri

Pasar bebas membantu pemerintah untuk memenuhi kebutuhan dalam negeri. Tidak semua barang dapat diproduksi di dalam negeri, sebagian barang harus diimpor untuk dapat memenuhi kebutuhan. Tidak adanya biaya impor dan persaingan ketat akibat pasar bebas membuat pemerintah dapat memenuhi kebutuhan dalam negeri dengan harga yang lebih murah. 


\section{Fungsi pasar bebas}

Pasar bebas memiliki fungsi didalam perekonomian negara diantara nya akan dibahas dibawah ini.

1. Pasar bebas bisa memberikan informasi dan juga lebih tepat tentang harga dan juga jumlah permintaan barang.

2. Pasar bebas dapat memberikan perangsang pada para pengusaha agar dapat mengembangkan usaha mereka.

3. Pasar bebas juga dapat memberikan perangsang pada para pengusaha agar dapat memperoleh keahlian yang modern.

4. Pasar bebas juga dapat memberikan dan juga merangsang penggunaan barang dan juga factor produksi dengan cara yang lebih efisien.

5. Pasar bebas dapat memberikan kebebasan dengan sepenuhnya pada masyarakat agar dapat melakukan kegiatan ekonomi. (w, 20-43) 


\section{Sejarah sistem pasar bebas}

Sistem pasar bebas pertama kali berasal dari bahasa prancis Laissez yang memiliki arti biarlah mereka menjalankan pekerjaan sesuai dengan keinginan mereka.

Dalam hal ini masyarakat memiliki kesempatan dan juga kebebasan yang penuh untuk dapat menentukan kegiatan ekonominya yang akan mereka lakukan. Didalam sistem pasar bebas apa yang diinginkan oleh konsumen akan langsung dicetuskan ke pasar dan juga sebagai dasar untuk mengalokasikan sumberdaya yang sangat terbatas.

Contohnya jika cenderung konsumen banyak menginginkan ikan,dan kemudian akan dinaikan harga ikan oleh para pedagang. Dan jika harga ikan dipasar akan mengalami kenaikan jelas akan mendorong perusahaan penangkapan dan juga pelelangan ikan akan lebih banyak menyediakan jam kerja agar dapat menangkap ikan dan juga mengolah ikan tersebut. (nara, 2019)

Dan jika ada yang mau menanamkan modalnya agar dapat memperbanyak kapal untuk penangkapan ikan, dan selanjutnya penawaran yang akan 
melebehi dari pada permintaan konsumen yang akan membuat harga kembali turun dan secara perlahan permintaan konsumen akan meningkat kembali. Penyesuaian yang seperti ini lebih sering disebut dengan the invisible hand (tangan yang tidak terlihat) yang menjadi sebuah mekanisme sistem pasar bebas didalam mengarahkan keputusan ekonomi.

Ungkapan yang sangat terkenal ini yang diutarakan oleh Bapak ekonomi modern Adam Smith didalam bukunya yang telah ditulisnya The Wealth Of Nation di tahun 1776. Adam Smith yang membuat bukunya disaat kondisi dunia intelektual dan diliputi serta dikuasai dengan idiologi besar.

Idiologi besar itu adalah liberalism, idiologi tersebut pada dasarnya mengajarkan tentang kebebasan dan juga menjunjung tinggi martabat manusia. Sistem pasar bebas menganut sistem yang kapitalis sedangkan pengertian dari kapitalis ialah suatu sistem dimana harta benda yang dimiliki dan juga dikendalikan oleh masyarakat dan setiap laba yang telah dihasilkan yang menggunakan harta milik pribadi akan menjadi hak dari pemilik harta itu.

Alasan dan juga motifasi untuk mencari laba dan juga mengumpulkan harta kekayaan kemudian dipercayai sebagai factor pendorong paling besar yang kemudian menyebabkan keberhasilan dari sistem ini. 


\section{Manfaat pasar bebas}

Pasar bebas memiliki manfaat yang bisa dirasakan dalam pertumbuhan perekonomian sebuah negara. Manfaat-manfaat yang dirasakan adalah, setiap orang menjadi bebas dalam memiliki kekayaan dan mengolah sumber daya produksi mereka.

Dengan begitu, kreativitas dari masyarakat akan lebih berkembang.

Lalu, karena pasar bebas menghasilkan persaingan, tiap produsen menjadi dituntut untuk menciptakan produk produk yang berkualitas.

Tindakan para pengusaha pun menjadi lebih efisien dan efektif karena mereka bergerak atas dasar prinsip ekonomi 


\section{Kelemahan pasar bebas}

Meskipun terkesan menguntungkan, bukan sistem ekonomi pasar ekonomi itu sempurna, lho.

Metode ini memiliki beberapa kelemahan yang harus diperhatikan pegiat bisnis. Nah, kira-kira, seperti apa kekurangan yang dimiliki sistem ekonomi pasar bebas? Berikut penjelasannya:

\section{Kualitas produk yang kurang baik}

Menurut Intelligent Economist, kekurangan utama dari free market adalah kualitas produk yang kurang memadai.

Hal ini terjadi karena tanpa sangkut paut pemerintah, tujuan utama perusahaan adalah untuk memaksimalkan jumlah profit.

Terkadang, untuk mencapai target tersebut, perusahaan tak ragu memotong biaya untuk keperluan produksi. Hasilnya, produk yang diciptakan kurang berkualitas.

\section{Monopoli perusahaan besar}

Berikutnya, monopoli perusahaan raksasa merupakan kelemahan besar dari sistem ekonomi pasar bebas. 
Hal ini terbentuk karena preferensi customer terhadap satu perusahaan. Jika perusahaan ini terus menguasai puncak pasar, institusi lainnya bisa mengalami kerugian.

Selain itu, perusahaan besar ini juga bisa menciptakan kapitalisasi pasar dengan nilai yang berat sebelah.

\section{Melonjaknya angka pengangguran dan ketidaksetaraan}

Dalam ekonomi free market, kelompok masyarakat seperti orang tua, anak-anak, dan orang yang tidak memiliki keterampilan khusus tidak akan dapat bekerja.

Mereka akan ditinggalkan oleh perekonomian dan hidup tanpa pendapatan apa pun.

Hal inilah yang nantinya akan menyebabkan peningkatan angka kemiskinan dan ketidaksetaraan kelas. (ahmad, 2017) 


\section{DAFTAR PUSTAKA}

ahmad, r. (2017). pasar bebas dalam perspektif islam. jurnal ekonomi islam, 4(2), $45-65$.

Nainggolan. (2018). strategi pengembangan bisnis di era pasar bebas. jurnal ekonomi , 3(2), 65-75.

nara, m. (2019). indutsri kreatif di era pasar bebas. jurnal penelitian hukum, 6(4), 43-65.

w, p. (20-43). kepemimpinan di era pasar bebas. jurnal hukum, 54.

wijayanti. (2016). ekonomi pasar bebas. jurnal ekonomi islam, 5(4), 33-45. 